\title{
POLYMORPHISMS IN CCL2\&CCL5 CHEMOKINES/CHEMOKINE RECEPTORS GENES AND THEIR ASSOCIATION WITH DISEASES
}

\author{
Zdenka Navratilova
}

\author{
Department of Immunology, Faculty of Medicine and Dentistry, Palacky University, Olomouc, Czech Republic \\ e-mail:navratilz@yahoo.com
}

Received: October 19, 2006; Accepted: November 21, 2006

Key words: Chemokines/CCL2/CCR2/CCL5/CCR5/Gene polymorphisms

Background: Chemokines and chemokine receptors are major mediators of leukocyte trafficking into the sites of the immune response. They participate in defence against microbial infection, in Th1/Th2 polarization of the immune response, allograft rejection and angiogenesis/angiostasis as well as in tumorigenesis and metastasis. To date, several functional polymorphisms of chemokine and chemokine receptor genes have been discovered that are able to deregulate chemokine system and, therefore, they may interfere with the pathogenesis of a large number of inflammatory and other diseases. In this review we focus on the known polymorphisms of two chemokines: CCL2, CCL5 and their corresponding receptors (CCR2, CCR5) and we also discuss their associations with susceptibility and progression to selected immune-mediated diseases.

Methods And Results: Based on relevant literature this article gives a short overview of case-control and family studies regarding effect of the genetic factors on diseases such as coronary artery disease, systemic lupus erythematosus, diabetes mellitus, lung diseases and others.

Conclusion: Recent advance in the identification of chemokine genetic background of the diseases could provide opportunity for pharmacological treatment. However, we need more information about posttranscriptional events to understand functional relevance of polymorphisms and to discovery new avenues to blocking disease development.

\section{INTRODUCTION}

Chemokines are low-molecular-weight molecules characterized by the presence, as a common structural pattern, of four cysteine residues and are divided into four main families ( $\mathrm{CXC}, \mathrm{CC}, \mathrm{C}$ and $\mathrm{CX} 3 \mathrm{C}$ ) according to the number of amino acids between the residues of the two most amino-proximal cysteines ${ }^{1,2}$.

Chemokines are trophic molecules; that is, they signal leukocytes to move in a specific direction, along gradient of chemokine concentration. Besides this, they are also involved in various processes unrelated to leukocyte migration, including cell proliferation and direct activation of mast cells, basophils, fibroblasts and others. In addition, chemokines can affect Th1/Th2 polarization of the immune response $\mathrm{e}^{1,3}$. Chemokine-induced signalling is mediated by a group of $\mathrm{G}$ protein-coupled receptors. Based on the sequence homology, two major chemokine receptor groups have been described: the CCR and the CXCR receptors.

Up- or down-regulation of chemokine and chemokine receptor expression has been observed in broad range of inflammatory and autoimmune diseases and is thought to be able to affect disease susceptibility, progression as well as severity. Recently, several polymorphisms have been shown to be responsible for the chemokine deregulation in vitro and in vivo ${ }^{4,5,6,7}$.
DNA polymorphism is defined as a DNA sequence variation in the population with the frequency of the rare allele equal to 1 percent or higher. A single nucleotide polymorphism (SNP), originating from one nucleotide substitution, can increase or decrease transcription activity if it is located in the regulatory region of the gene. Nucleotide substitutions or insertions/deletions in the coding sequences of genes can cause qualitative changes of proteins. Accordingly, several polymorphisms in the genes encoding proteins important in the pathogenesis of particular diseases have been associated with disease susceptibility or severity. This review is focused on the known polymorphisms of two chemokines: CCL2, CCL5, their corresponding receptors (CCR2, CCR5) and their associations with diseases. Some of these associations are listed in Table 1.

\section{CCL2/MCP-1 (Monocyte chemoattractant protein-1)}

\subsection{Biological function of CCL2}

CCL2 is the member of the CC chemokine subfamily characterised by the absence of amino acid between conserved cysteines at amino-terminal end of the molecule. The concentration gradient of CCL2 is responsible for the movement of mononuclear cells, mainly monocytes/ 
Table1. CCL2, CCL5, CCR2 and CCR5 polymorphisms and their associations with particular diseases.

The numbers in cells response studies of reference list.

\begin{tabular}{|c|c|c|c|c|c|}
\hline 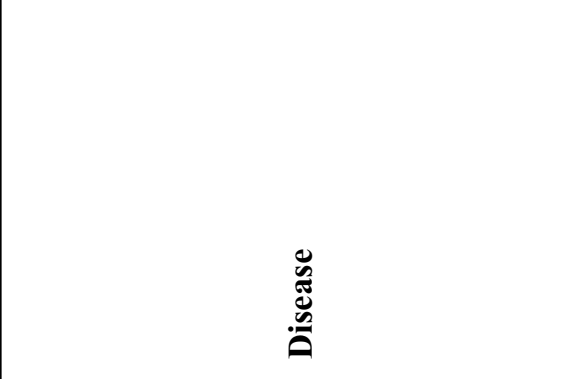 & 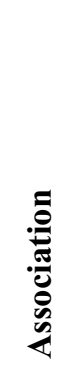 & 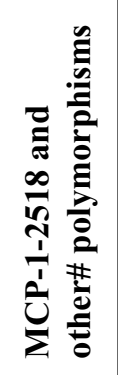 & 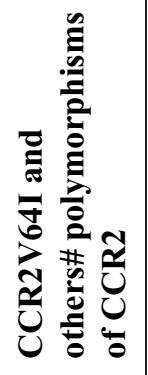 & 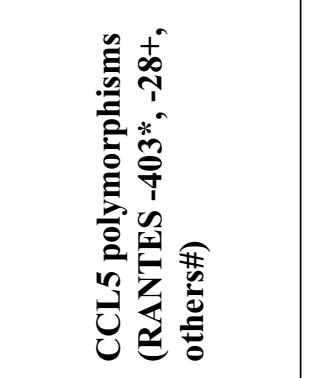 & 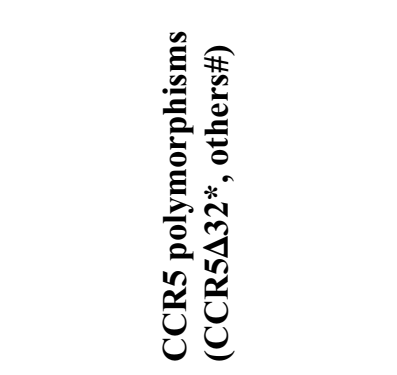 \\
\hline Atherosclerosis & No & 23 & $\begin{array}{c}15,56 \\
143\end{array}$ & & \\
\hline Atherosclerosis in HIV-infected patients & Yes & 144 & & & \\
\hline \multirow{2}{*}{ Coronary artery disease } & Yes & 15 & & $16^{*}$ & \\
\hline & No & 16 & 15 & $15^{*+}$ & $15^{*}, 16^{*}$ \\
\hline \multirow{2}{*}{ Myocardial infarction } & Yes & 39 & 54,143 & & $55^{*}$ \\
\hline & No & $18 \#$ & 18,55 & & $108^{*}$ \\
\hline Stroke history & Yes & 17 & & & \\
\hline Coronary Artery Calcification & Yes & & 56 & & $109^{*}$ \\
\hline Abdominal aortic aneurysma & Yes & & & & $107^{*}$ \\
\hline \multirow{2}{*}{ Multiple sclerosis } & Yes & & 61 & $78^{*+}$ & $62^{*} 110^{*}, 111^{*}, 112^{*}, 114^{*}$ \\
\hline & No & 23 & 62 & & $113^{*}$ \\
\hline Systemic sclerosis & Yes & 24 & & & \\
\hline \multirow{2}{*}{ Rheumatoid arthritis } & Yes & 25 & & $99^{*+}, 100 *$ & $115^{*}, 116^{*}, 117^{*}$ \\
\hline & No & 26 & & & \\
\hline \multirow{2}{*}{ Asthma and atopy } & Yes & 20 & & $80^{*}, 81^{*}, 82^{*+}, 83+$ & $119^{*}$ \\
\hline & No & 145 & & $20^{*+}, 83^{*}, 84^{*+}$ & $120^{*}, 121^{*}$ \\
\hline $\begin{array}{l}\text { Atopic eczema/dermatitis syndrome, } \\
\text { atopic dermatis }\end{array}$ & No & 21 & & $21^{*+}$ & \\
\hline \multirow{2}{*}{ Pulmonary sarcoidosis } & Yes & & $57,59 \#$ & & $58^{*}, 118 \#$ \\
\hline & No & 22 & $44 \#, 58$ & $86^{*}$ & \\
\hline Type 1 diabetes & Yes & & & & $131^{*}, 132^{*} \#$ \\
\hline \multirow{2}{*}{ Type 2 diabetes } & Yes & 36 & & $77 * \#$ & $131^{*}$ \\
\hline & & 77 & & $77+$ & \\
\hline \multirow{2}{*}{ Diabetic nephropathy } & Yes & & & $92+\#$ & $133 \#$ \\
\hline & No & & 133 & $92 *$ & \\
\hline \multirow{2}{*}{ Hepatitis $\mathrm{C}$ virus infection } & Yes & 40,41 & & $72 *, 96^{*}$ & $71^{*}, 72^{*}, 134^{*}, 135^{*}$ \\
\hline & No & 72 & 71,72 & $71^{*}$ & $96^{*}$ \\
\hline Kidney graft rejection & Yes & 69 & & & $138 \#$ \\
\hline
\end{tabular}


Table 1. Continues

\begin{tabular}{|c|c|c|c|c|c|}
\hline \multirow{2}{*}{ Liver graft rejection } & Yes & & & & $139 *$ \\
\hline & No & 39 & 68 & $39 *+, 98 *+$ & $39 *, 68 \#$ \\
\hline \multirow{2}{*}{ Renal graft rejection } & Yes & & 70 & & 70\# \\
\hline & No & & 38 & & $70^{*}$ \\
\hline \multirow{2}{*}{ Heart rejection } & Yes & & & $69^{*}$ & $137 *, 69 \#$ \\
\hline & No & & 69 & & \\
\hline \multirow{2}{*}{ Systemic lupus erythematosus (SLE) } & Yes & 35 & & $93+, 94 *+$ & \\
\hline & No & 93 & 140 & $93 *$ & $140^{*}$ \\
\hline Lupus nephritis & Yes & 34,35 & & & $140^{*}$ \\
\hline \multirow{2}{*}{ Alzheimer's disease } & Yes & 42 & & & \\
\hline & No & 42 & & & \\
\hline $\begin{array}{l}\text { Dementia or neurocognitive impairment } \\
\text { in HIV-1 infected patients }\end{array}$ & Yes & 27 & & & $129^{*}$ \\
\hline \multirow{2}{*}{ Breast cancer } & Yes & 37 & 73 & & $141^{*}$ \\
\hline & No & & & $37 *$ & $73 * \#, 37 *$ \\
\hline
\end{tabular}

macrophages, to sites of inflammation ${ }^{1,2}$. CCL2 is produced by a variety of cell types, including macrophages, lymphocytes ${ }^{2}$, neutrophils ${ }^{8}$, vascular endothelial cells ${ }^{9}$, fibroblasts, keratinocytes ${ }^{10}$ and several cancer cell lines ${ }^{11}$. These immune and non-immune cells produce CCL2 in response to stimulation by a broad area of mediators including cytokines ${ }^{9}$, growth factors ${ }^{10,12}$ and lipopolysaccharides ${ }^{8}$ suggesting an CCL2 role in host defence against bacteria.

\subsection{CCL2 gene and its polymorphisms}

\subsubsection{Localisation}

Mehrabian et al. localized the gene for CCL2 on chromosome 17. By in situ hybridization, they localized the gene to $17 \mathrm{q} 11.2-\mathrm{q} 21.1^{13}$. By a combination of in situ hybridization and a study of somatic cell hybrids, Rollins et al. assigned the gene to $17 \mathrm{q} 11.2-\mathrm{q} 12^{14}$. They pointed out that CCL2 belongs to a family of cytokines which can be grouped into 2 subfamilies based on structure and chromosomal location, namely $17 \mathrm{q}$ and $4 \mathrm{q}^{14}$.

\subsubsection{Polymorphisms}

In this study we summarise current data for seven MCP-1 polymorphisms that have been studied in relationship to disease susceptibility or severity. Four have been described in the distal regulatory region of the MCP-1 gene: $-1811 \mathrm{~A} / \mathrm{G},-2136 \mathrm{~A} / \mathrm{T},-2518 \mathrm{~A} / \mathrm{G},-2835 \mathrm{C} / \mathrm{A}$; one in promoter region: $-927 \mathrm{G} / \mathrm{C}$; one in the first intron: 764 $\mathrm{C} / \mathrm{G}$ and one in the 3' flanking region: $3726 \mathrm{~T} / \mathrm{C}$. These seven CCL2 SNPs delineate 6 common haplotypes (H1 through $\mathrm{H} 6)^{4}$.
Four of the above mentioned SNPs $\left(-2136^{*}\right.$ T, $\left.-2518^{*} \mathrm{G},-2835^{*} \mathrm{~A}, 764^{*} \mathrm{G}\right)$ in the CCL2 gene were found to be associated with increased levels of MCP-1 protein ${ }^{4}$. To our knowledge, the majority of case-control studies concentrated on the MCP-1-2518 SNP and, therefore, we will mainly focus on the relation of this polymorphism to disease pathophysiology.

1.3 Diseases associated with MCP-1-2518 SNP and other SNPs in the gene encoding CCL2 chemokine

\subsubsection{Atherosclerosis and myocardial infarction (MI)}

CCL2 is thought to play an important role in initiating and mediating atherosclerosis: circulating blood monocytes recruited to the cell wall serve as the precursors of the foam cells that form fatty streaks-the hallmark of early atherosclerotic lesions ${ }^{3}$. Moreover, CCL2 might also contribute to the thrombotic aspects of advanced atherosclerotic lesions, a late complication of atherosclerosis responsible for myocardial infarctions and strokes ${ }^{3}$. In addition, CCL2 expression is up-regulated in human atherosclerotic plaques ${ }^{3}$ suggesting that genetic factors leading to deregulation of CCL2 production could affect development of atherosclerosis and atherosclerosis-associated diseases. In this context Szalai et al. found the frequency of the MCP-1-2518*G allele homozygotes significantly higher in coronary artery disease (CAD) patients than in healthy controls ${ }^{15}$. However, this association was not replicated in the subsequent larger study ${ }^{16}$. The higher prevalence of MCP-1-2518* $\mathrm{G}$ homozygotes was observed in patients with history of stroke ${ }^{17}$ and myocardial infarction ${ }^{4}$. In agreement with the report of Simeoni ${ }^{16}$, 
MCP-1-2518 SNP was not associated with ischemic heart disease in an Irish population ${ }^{18}$.

\subsubsection{Lung diseases}

In 1997 a genome-wide search found evidence for linkage of asthma to chromosome 17p11.1-q11.2 (CC chemokine cluster $)^{19}$. Subsequently, several studies were conducted to explore possible association of MCP-1-2518 A/G SNP with asthma. In 2001 Szalai et al. showed higher prevalence of MCP-1-2518* $\mathrm{G}$ allele in asthmatic children than in controls and nonasthmatic atopic children ${ }^{20}$. In addition, the GG genotype correlated with asthma severity and the $\mathrm{G}$ allele was associated with increased blood eosinophil levels ${ }^{20}$. However, there was no association between MCP-1-2518 and atopic eczema/dermatitis syndrome or allergy in a cohort of Hungarian children ${ }^{21}$.

In case of sarcoidosis, MCP-1-2518 does not play a substantial role in the disease susceptibility, but might be related to the recruitment of monocytes/macrophages to the alveolar spaces in Japanese patients with sarcoidosis ${ }^{22}$.

\subsubsection{Systemic sclerosis (SSc)}

$\mathrm{SSc}$ is an autoimmune disease of the skin or internal organs and is characterized by increased synthesis of connective extracellular matrix. Karrer et al. found that homozygotes for MCP-1-2518*G allele were more common in SSc patients compared to controls ${ }^{24}$.

\subsubsection{Rheumatoid arthritis $(R A)$}

MCP-1-2518 A/G polymorphism is associated with the susceptibility to RA in patients lacking the specific HLA epitope, which is the risk factor for RA acquiring ${ }^{25}$. When patients were not stratified according to the HLA status, distribution of MCP-1-2518 A/G polymorphism was similar in patients and healthy controls ${ }^{26}$.

\subsubsection{HIV infection}

Associations of genetic polymorphisms with HIV-1 infection have been intensively studied predominantly for the chemokine receptors, but only a few studies on chemokine genes exist. Gonzalez et al. reported decreased risk of acquiring HIV-1 in homozygotes and heterozygotes for the MCP-1-2518* $\mathrm{G}$ allele ${ }^{27}$. The protective effect could be mediated through CCL2 overproduction ${ }^{28}$ limiting HIV infection access to CCR2 that is a minor co-receptor for $\mathrm{HIV}^{29}$. On the other hand, homozygosity for MCP$1-2578 * \mathrm{G}$ was also associated with accelerated progression to AIDS and death ${ }^{27}$. Additionally, the association of higher CCL2 level with more advanced HIV disease was described $^{30}$. Gonzalez et al. summarized that CCL2 can attract HIV infected macrophages that may disseminate the virus to different organs ${ }^{27}$. Thus, CCL2-mediated recruitment of macrophages and activation can also fuel HIV-1 pathogenesis. These findings indicated that the beneficial influence of MCP-1-2518 SNP does not occur once HIV-1 infection is established ${ }^{27}$.

There is evidence implicating the MCP-1-2518*G allele as a critical factor in the pathogenesis of various diseases accompanying HIV infection. Thus, the study by Alonso- Alonso-Villaverde et al. showed that HIV-infected patients with the MCP-1-2518*G allele have a 5fold increased risk for atherosclerosis ${ }^{144}$. Furthermore, GG homozygotes had 4.7-fold higher likelihood of developing HIV-associated dementia ${ }^{27}$. Higher levels of CCL2 chemokine in cerebrospinal fluid ${ }^{27,28}$ can increase the capacity of HIV-infected leukocytes to transmigrate through the blood-brain barrier ${ }^{31}$. By contrast, Singh et al. failed to find any association of MCP-1-2518 A/G SNP with neuropsychological impairment in HIV patients ${ }^{32}$. In addition, Modi et al. studied two other CCL2 SNPs (-2136 A/T located in the promoter region and $767 \mathrm{C} / \mathrm{G}$ located in intron 1) and described elevated $\mathrm{H} 7$ haplotype (MCP-1-2136*T and $767 * \mathrm{G}$ with $-1385 * \mathrm{~A}$ in the Eotaxin promoter) in uninfected European-Americans repeatedly exposed to HIV-1 through high-risk sexual behaviour or contaminated blood products ${ }^{33}$.

\subsubsection{Systemic lupus erythematosus (SLE)}

Two papers have reported an association of MCP1-2518 A/G polymorphism with clinical manifestation of SLE in terms of renal involvement toward lupus nephritis $^{34,35}$. In addition, Tucci et al. suggest that an A/ $\mathrm{G}$ or $\mathrm{G} / \mathrm{G}$ genotype may predispose to the development of $\mathrm{SLE}^{35}$.

\subsubsection{Other diseases}

Tumor infiltrating lymphocytes and tumor associated macrophages are thought to play a crucial role in tumour immune surveillance and development. In breast cancer patients, Ghilardi et al found no differences in the distribution of MCP-1-2518 A/G variants compared with controls ${ }^{37}$. However, the authors observed a correlation between the presence of at least one $G$ allele and the presence of metastasis ${ }^{37}$. Considering involvement of leukocyte infiltration in allograft rejection, detection of genetic markers for CCL2 upregulation could also be helpful for predicting the outcome of transplantation. In this context, Kruger et al. showed that MCP-1-2518 GG genotypes of kidney graft recipient reduce long-term graft survival $^{38}$. On the other hand, Schroppel et al. genotyped liver transplant recipients for MCP-1-2518 SNP and failed to show any association with the incidence of acute rejection episodes or long-term liver graft survival ${ }^{39}$.

Muhlbauer et al. investigated the correlation of MCP1-2518 A/G SNP with hepatic CCL2 expression and disease outcome in patients with hepatitis C. MCP-1-2518* $\mathrm{G}$ allele carriers were more common in hepatitis $C$ virus (HCV) infected patients with more advanced fibrosis and severe inflammation ${ }^{40}$. In contrast, subsequent study showed that the frequency of the $\mathrm{G}$ allele and the $\mathrm{G}$ allele carriers were decreased in chronic HCV infection and the differences were not observed when compared to patients with or without cirrhosis ${ }^{41}$.

In an Italian population, MCP-1-2518 GG genotype and $\mathrm{G}$ allele were associated with Alzheimer's disease ${ }^{42}$, but this data was not confirmed in Spanish population ${ }^{42}$. 


\section{CCR2}

\subsection{Biological function of CCR2}

CCR2 is a promiscuous $\mathrm{CC}$ chemokine receptor with an affinity for CCL2, CCL7, CCL8 and CCL13 ligands ${ }^{1,43}$. CCR2 is mainly expressed by memory $\mathrm{T}$ lymphocytes, monocytes, dendritic cells, B cells and basophils. Neutrophils also can express CCR2 but only under specific conditions ${ }^{1,43}$.

CCR2 has two isoforms, CCR2A (360 amino acids) and CCR2B (374 aa), which differ only in their terminal carboxyl tails. These amino acid sequences located in the terminal carboxyl tail determine good CCR2B transportation to the cell surface, whereas the major part of CCR2A is located in the cytoplasm. CCR2B is the predominant isoform in monocytes and the levels of both CCR2A and CCR2B decrease as the monocytes differentiate into the macrophages.

\subsection{CCR2 gene and its polymorphisms}

\subsubsection{Localisation}

The CCR2 gene is located on chromosome 3p21-p24 in a $\mathrm{CC}$ chemokine receptor cluster in proximity to the CCR1, CCR3, CCR4, and CCR5 genes ${ }^{43}$.

In this review we discuss in total nine biallelic CCR2 SNPs, in which relationship with varied disease susceptibility or severity was studied. They are located in the CCR2 gene at the following nucleotide positions: -6928 G/T,-6752 A/G, 190 G/A, 840 C/T, 3000 A/G, 3547 T/C, 3610 A/G, 3671 C/G, 4385 T/A. Apart from SNP $840 \mathrm{C} / \mathrm{T}$, the remaining eight SNPs form nine haplotypes (haplotypes 1-9) ${ }^{59}$. In addition, a complete linkage disequilibrium between $840 \mathrm{C} / \mathrm{T}$ and $4385 \mathrm{~A} / \mathrm{T}$ variants has been shown by Valentonyte et al. ${ }^{44}$.

\subsubsection{CCR2V64I polymorphism and its functional conse- quence}

The mostly studied CCR2 SNP is $190 \mathrm{G} / \mathrm{A}$ located in exon 1. It has been shown that its distribution is strongly dependent on ethnicity ${ }^{45,46,47,48}$. Its mutation leads to the substitution of valine by isoleucine (V64I) in the transmembrane region of the protein. Data on the influence of this SNP on the expression of CCR2 are controversial. In the literature there are both evidence for CCR2V64I function $^{49}$ as well as lack of effect on CCR2 expression ${ }^{50}$. Nakayama et al. observed up-regulation of CCR2A-64I compared to CCR2A without substitution ${ }^{49}$. Accordingly, a chemotaxis assay showed that cells expressing CCR2A64I migrated more efficiently than those expressing CCR2A-64V, in spite of the fact that CCR2A mostly localized in cytoplasm and only a small portion observed on the cell surface. By contrast CCR2B expression was not affected by this mutation. Furthermore, pulse-chase experiments have revealed that higher expression of CCR2A-64I was due to increased stability of CCR2A-64I ${ }^{49}$. Although these data suggest an association of CCR2V64I with in- creased CCR2A expression on the cell surface, it does not seem to be a unique property of this SNP. In parallel, the authors also measured CCR 5 surface expression that was more severely blocked by co-expression of CCR2A-64I than by CCR2A-64V. Furthermore, this negative effect of CCR2A on CCR5 expression was shown to arise from the possibility of heterodimer formation between CCR2A and CCR5. CCR2A has been even suggested to recognise CCR5 in immature form and may interfere with the maturation process of CCR5 molecules in the cytoplasm. Similarly, HIV-1 co-receptor activity of CCR5 was more dramatically reduced by co-expression of CCR2A-64I than by co-expression of CCR2A-64V. Taken together, the authors concluded that CCR2A-64I polymorphism modulates CCR5 surface expression ${ }^{49}$. By contrast, a previous study showed that CCR2V64I mutation does not affect the surface expression or co-receptor activity of CCR5 on co-transfected cell lines ${ }^{50}$. Although CCR2V64I slightly decreased CCR5 expression levels in CD4+T and peripheral blood mononuclear cells, this difference was not statistically significant ${ }^{50,51}$. Nakayama et al. speculated that the negative effect of CCR2V64I on CCR5 expression could be limited to specific cell types ${ }^{49}$. Moreover, one study suggested that surface CCR5 expression appears to be a poor predictor of either its internalization or reexpression. In this context, CCR2V64I polymorphism was indicated to decrease CCR5 reexpression after ligandinduced internalization in $\mathrm{CD} 4^{+} \mathrm{T}$ cells ${ }^{52}$.

\subsection{Diseases associated with CCR2 polymorphisms}

\subsubsection{Atherosclerosis and MI}

Ortlepp et al. studied CCR2V64I SNP distribution in patients with $\mathrm{MI}$ and atherosclerosis ${ }^{53}$. The authors found that CCR2 VI/II genotypes were significantly associated with MI in patients younger than 65 years $^{53}$. Similarly, the relationship of VI genotype with an early onset of MI in females was reported ${ }^{54}$. In both studies, age limitation is in agreement with the recent hypothesis that genetic factors may have impact on MI patients with onset only before the age of 65 years ${ }^{53,54}$. In contrast, no association of this SNP with MI was found in Spanish or Icelandic cohorts $^{18,55}$.

Additionally, patients with the rare allele CCR2-64I have less coronary artery calcification ${ }^{56}$, but there was no association of the CCR2 genotype with coronary atherosclerosis ${ }^{53}$.

\subsubsection{Lung diseases}

To date, four reports studying the CCR2 gene in association with sarcoidosis exist. In Japanese patients, CCR2-64I reduced the risk of sarcoidosis ${ }^{57}$, but this observation was not confirmed in Czech or Dutch patients ${ }^{44,58}$. Valentonyte et al. also found no association with other CCR2 SNPs (190 G/A, $840 \mathrm{C} / \mathrm{T}$ or $4385 \mathrm{~A} / \mathrm{T})$ and sarcoidosis $^{44}$. Association of CCR2-haplotype 2 (A at nucleotide position -6752 , $\mathrm{A}$ at 3000 , $\mathrm{T}$ at 3547 , and $\mathrm{T}$ at 4385) was observed in patients presenting with Löfgren's 
syndrome, an acute form of sarcoidosis ${ }^{59}$. To date there are no data of possible association of CCR2V64I SNP with pulmonary fibrosis or asthma.

\subsubsection{Multiple sclerosis (MSc)}

In vitro studies have shown that CCL2/CCR2 interaction induces efficient transmigration of mononuclear cells across the microvascular endothelial layers of the brain $^{60}$. The most frequently studied CCR2V64I SNP could, therefore, affect the inflammatory process of MSc. CCR2-64I/64I genotype was shown protect against the development of MS in a Japanese population ${ }^{61}$. However, the authors found no association between genotypes and age at disease onset, disease progression index or clinical course such as relapse-remission or secondary progressive course. They speculate that this protection may be through intracellular interactions of mutant proteins with other chemokine receptors, such as CCR5, which influence MSc pathogenesis ${ }^{61}$. It is also possible that a mutation in another region of CCR2 may be directly responsible for the protective effect, because there was no association of CCR2V64I with MSc in a family-based study of Canadian patients ${ }^{62}$

\subsubsection{HIV infection}

CCR2 is utilized as a minor HIV co-receptor with no exactly established tropism. CCR2-64I variant is thought to provide protection against progression to AIDS, but it does not influence the acquisition HIV-1 infection ${ }^{45,63,64,65,66}$. A recent study even reported CCR2V64I SNP association with HIV-1 infection susceptibility ${ }^{67}$.

\subsubsection{Other diseases}

CCR2V64I mutation had no effect on kidney, liver or heart graft failure ${ }^{38,68,69}$. However a significant reduction in the risk of acute renal transplant rejection was found in recipients who possessed the CCR2-64I allele ${ }^{70}$. Further, CCR2V64I was explored in patients infected with hepatitis $\mathrm{C}$ virus (HCV) and negative results were reported ${ }^{71,72}$. Furthermore, current findings suggest that CCR2V64I polymorphism might have a protective role against breast cancer development ${ }^{73}$.

\section{CCL5/RANTES (RANTES, Regulated upon Activation, Normal T cell Expressed and Secreted)}

\subsection{Biological function of CCL5 chemokine}

CCL5 is a potent chemoattractant for memory T lymphocytes, monocytes and eosinophils ${ }^{1}$, its function is not only mediated by CCR 5 but also CCR 1, CCR 3 and other receptors ${ }^{1}$. CCL5 was found to be highly expressed in activated $\mathrm{T}$ lymphocytes, macrophages, fibroblasts, platelets, mesangial cells, epithelial cells, megakaryocytes and some tumours ${ }^{1}$

\subsection{CCL5/RANTES gene and its polymorphisms}

The CCL5 gene is located on the short arm of chromosome 17(17q11.2-q12)1.

This part of the review combines data on seven SNPs within the CCL5 gene: four SNPs located in the promoter region: $-28 \mathrm{C} / \mathrm{G},-109 \mathrm{C} / \mathrm{T},-105 \mathrm{C} / \mathrm{T},-403 \mathrm{G} / \mathrm{A}$; two SNPs in the first intron: Int1.1 T/C and Int $1.2 \mathrm{G} / \mathrm{A}$ and one SNP in an Alu-related repeat area of the 3' untranslated region: 3' $222 \mathrm{~T} / \mathrm{C}$. Four of the above mentioned SNPs (-403 G/A, -28 C/G, In1.1 T/C, and 3'222 T/C) form 5 common haplotypes with the most frequent being the haplotype 1 with the common alleles at positions -403, -28 , In 1.1 , and $3^{\prime} 222^{6}$. It should be noted that the haplotype distribution is dependent on ethnicity ${ }^{5,76}$.

The functional effect of RANTES-403 G/A, $-28 \mathrm{C} / \mathrm{G}$ and In $1.1 \mathrm{~T} / \mathrm{C}$ SNPs was confirmed in several reporter assay systems ${ }^{5,6}$.

\subsection{Diseases associated with CCL5 polymorphisms}

\subsubsection{Atherosclerosis}

When Simeoni et al. explored distribution of RANTES-403 G/A in coronary artery disease (CAD), $-403 * A$ variant was associated with increased risk of CAD and it remained significant after multivariate adjustment ${ }^{16}$. Furthermore, Boger et al. reported an association of cardiovascular events as main cause of mortality in patients with type 2 diabetes with carriage of RANTES-403*A or In $1.1{ }^{*} \mathrm{C}$ alleles ${ }^{77}$.

\subsubsection{Multiple sclerosis $(\mathrm{MSc})$}

A case-control study showed that RANTES-403 G/A polymorphism is associated with more than double higher risk of susceptibility to MSc. RANTES-28 G/C is associated with both early onset and longer survival of MSc patients $^{78}$.

\subsubsection{Lung diseases}

The airway inflammation characteristic for asthma involves CCL5 up-regulation leading to associated tissue eosinophilia. Furthermore, the genome-wide search for asthma and atopy susceptibility genes points to the CCL5 gene ${ }^{79}$. In this context, a case-control study found that RANTES-403*A allele increases disease susceptibility to both atopy and asthma in Caucasian subjects ${ }^{80}$. In agreement with this, a recent study reported that the RANTES-403*A allele is transmitted with atopy and atopic asthma, although its contribution appears to relate more to atopy than to asthma ${ }^{81}$. By contrast, RANTES-403 G/A polymorphism did not influence asthma susceptibility in Chinese or Hungarian children and in a Japanese population ${ }^{20,82,83}$ or atopy susceptibility in Chinese children $^{82}$ or allergy in Hungarian children ${ }^{20}$.

Along with RANTES-403 C/G SNP, the effect of RANTES-28 C/G SNP on asthma susceptibility has also been studied. RANTES-28 C/G SNP correlates with the numbers of peripheral eosinophils and with asthma 
severity in a Chinese population ${ }^{82}$. On the other hand, one study reported an association of RANTES- $28 * \mathrm{G}$ allele with late-onset asthma in a Japanese population ${ }^{83}$ and others observed the absence of RANTES-28 C/G association with asthma in Hungarian children ${ }^{20}$ or with atopy ${ }^{82,84}$. Yao et al. further analysed haplotype distribution of RANTES-403G/A and $-28 \mathrm{C} / \mathrm{G}$ and observed that the haplotype $3(-403 * \mathrm{G},-28 * \mathrm{G})$ was more common in a near-fatal asthma group compared to mild-moderate asthma, atopy or a healthy control group ${ }^{84}$.

Furthermore, CCL5 over-production correlates with pulmonary sarcoidosis, particularly in patients with more advanced disease ${ }^{85}$. In agreement with this, Takada et al. suggested an association of RANTES-403 G/A polymorphism with the number of organs involved and CD4/ CD8 rate, but not with susceptibility to sarcoidosis as a whole ${ }^{86}$.

\subsubsection{HIV infection}

There are 5 common CCL5 SNPs $(-403 \mathrm{G} / \mathrm{A},-109$ $\mathrm{T} / \mathrm{C},-28 \mathrm{C} / \mathrm{G}, \mathrm{In} 1.1 \mathrm{~T} / \mathrm{C}$, and 3'222 T/C) that have been studied either separately or as 4 common haplotypes regarding HIV infection.

\subsubsection{Susceptibility to HIV infection}

Gonzalez et al. explored the distribution of RANTES-403 G/A, -28 C/G SNPs and RANTES haplotype pairs in HIV positive and HIV negative individuals in worldwide populations ${ }^{87}$. This study and others have showed that the evolutionary histories of human populations have had a significant impact on the distribution of variation in these genes, and that this may be responsible, in part, for the heterogeneous nature of the epidemiology of the HIV-1 pandemic ${ }^{5,87,88,89,90}$.

In European Americans, it has been observed that the ancestral haplotype pair AC/AC of RANTES-403 G/A and $-28 \mathrm{C} / \mathrm{G}$ SNPs is associated with higher risk of acquiring HIV-1 ${ }^{87}$. Further common haplotype pairs among European Americans (AC/GC GC/GC, and GC/AG) decrease susceptibility to HIV infection compared to the ancestral haplotype pair. However this association was not found in African Americans ${ }^{87}$. Furthermore, the haplotype pair AC/GC of RANTES-403/-28 SNPs was more common in seroconverter versus exposed-uninfected participants of Multicenter AIDS Cohort Study (MACS) ${ }^{89}$. In contrast, the haplotype pair GC/GC was more common in exposed-uninfected versus HIV positive individuals ${ }^{89}$. These data suggest that the RANTES-403*A allele is a risk factor for acquiring HIV, but may produce different phenotypes in distinct populations ${ }^{87,89}$.

By contrast to the MACS study Zhao et al. observed that the haplotype $1(-403 \mathrm{G},-28 \mathrm{C})$ and $-403 * \mathrm{G}$ allele are over-represented in Chinese HIV positive patients, whereas -403 A/A genotype was associated with lower susceptibility to HIV infection ${ }^{88}$. In a Hispanic population the haplotype ACT of three RANTES SNPs (-403 A/G, intron 1 C/T, 3' UTR 222 T/C) has protective effect, but this does not apply to African-American populations or other populations of North Americans with HIV-1 infection ${ }^{90}$. A Japanese study failed to find any effect of $-403 \mathrm{~A} / \mathrm{G}$ or $-28 \mathrm{G} / \mathrm{C}$ on acquiring HIV infection ${ }^{5}$.

\subsubsection{Susceptibility to AIDS progression}

McDermott et al. studied the distribution of RANTES-403 G/A and -28 C/G SNPs and their compound genotypes in exposed-uninfected participants of the Multicenter AIDS Cohort Study (MACS) ${ }^{89}$. Here the haplotype pair RANTES-403 G/A and -28 C/C correlated with slower progression to AIDS compared to the haplotype pair RANTES-403 G/G and -28 C/C among seroconverters lacking CCR5 $\Delta 32$. These data imply that RANTES- $403 *$ A allele may be a protective factor for HIV progression. Haplotype pair AC/AC was associated with disease progression in European Americans, but not African Americans ${ }^{87}$. Furthermore, RANTES SNPs at positions $-28 \mathrm{C} / \mathrm{G},-109 \mathrm{~T} / \mathrm{C}$, and $-403 \mathrm{G} / \mathrm{A}$ were not associated with long-term nonprogressive HIV-1 infection in a Spanish white population ${ }^{91}$.

A Japanese case-control study found that haplotype $3(-403 * \mathrm{~A},-28 * \mathrm{G})$ correlates with slower rates of CD4+ lymphocyte depletion, suggesting that haplotype 3 may play a role in delaying AIDS progression ${ }^{5,87}$. By contrast, Chinese symptomatic HIV positive patients had a higher frequency of the $-28 * \mathrm{G}$ alelle and haplotype $3(-403 * \mathrm{~A}$, $-28 * \mathrm{G})$ compared to asymptomatic patients suggesting an effect on disease progression ${ }^{88}$.

Two studies explored the influence of four RANTES SNPs (-403 G/A and -28 C/G, In1.1 T/C and 3 $222 \mathrm{~T} /$ C) and their haplotypes related to HIV infection progression. An et al. found that haplotype 3 (which contains In $1.1{ }^{*} \mathrm{C}$ ) correlates with AIDS accelerating in AfricanAmericans and European-Americans ${ }^{6}$. Weaker association of the In $1.1^{*} \mathrm{C}$-containing haplotype 4 carriage with rapid AIDS progression was also evident in African-Americans, but not in European-Americans ${ }^{6}$. In African Americans, subsequently, Duggal et al. observed that homozygotes for the haplotype $1(-403 * \mathrm{G},-28 * \mathrm{C}, \mathrm{In} 1.1 * \mathrm{~T}$, and $3222 * \mathrm{~T})$ have lower viral load than individuals carrying at least one R2, R3, or R4 haplotype ${ }^{76}$. Additionally, after adjusting for potential confounders, including the CCR5 $\Delta 32$, CCR2 V64I, and CCR5 P1 promoter haplotypes, the strength of the association was even stronger for the R1 haplotype ${ }^{76}$.

\subsubsection{Diabetes mellitus}

The RANTES promoter $-28 * \mathrm{G}$ genotype may be a risk factor for diabetic nephropathy in patients with type 2 diabetes mellitus ${ }^{92}$. Boger et al. studied the effect of the functional polymorphisms in the RANTES gene on mortality in a collective of type 2 diabetes hemodialysed patients. Patients carrying the RANTES-403*A or In $1.1{ }^{*} \mathrm{C}$ alleles had $81 \%$ and a $46 \%$ higher risk for all-cause mortality, mainly due to cardiac events. Similar data were obtained by haplotype analysis ${ }^{77}$.

\subsubsection{Systemic lupus erythematosus (SLE) \\ In the Chinese population, children with RANTES-28 $\mathrm{C} / \mathrm{G}$ or $\mathrm{G} / \mathrm{G}$ genotypes have more than double the risk}


of SLE compared to those with the C/C genotype ${ }^{93}$. Subsequently, another Chinese study found that a compound genotype $-403 \mathrm{G} / \mathrm{G}$ and $-28 \mathrm{C} / \mathrm{C}$ correlated with a risk of SLE and $-403 * \mathrm{G}$ allele is probably related with renal damage ${ }^{94}$.

\subsubsection{Other diseases}

CCL5/CCR5 interaction is likely to be important during hepatitis $\mathrm{C}$ virus infection, where $\mathrm{T}$ cells are recruited to the liver parenchyma to mediate clearance of $\mathrm{HCV}$ infected hepatocytes ${ }^{95}$. Consistent with this hypothesis, RANTES-403 G/A SNP was observed to decrease risk of severe inflammation in Hepatitis $\mathrm{C}$ virus-seropositive patients heterozygous or homozygous for the RANTES promoter alleles $-403^{*} \mathrm{~A}^{96,72}$. By contrast, a recent study found no association of RANTES polymorphisms with disease outcome or severity of hepatitis $\mathrm{C}$ virus infection ${ }^{71}$.

Fleury et al. suggested a favourable role for antiRANTES therapy in heart transplantation reducing graft infiltration by monocytes/macrophages ${ }^{97}$. Accordingly, the carriers of RANTES-403*A allele are at higher risk of developing "late" outcome of acute heart transplant rejection, if they are carriers of CCR5 haplotype $\mathrm{E}$ at the same time ${ }^{69}$. On the other hand, RANTES-28 $\mathrm{C} / \mathrm{G}$ and $-403 \mathrm{G} / \mathrm{A}$ neither influenced the incidence of acute rejection nor affected allograft survival after liver transplantation ${ }^{39,98}$. Five years allograft survival, however, involved $61.3 \%$ liver recipients with the GG genotype of RANTES-403 G/A against 58.8\% recipients with the GA and AA genotypes ${ }^{98}$. This difference was also not statistically significant ${ }^{98}$.

Recent results indicate that RANTES-403 G/A SNP is associated with susceptibility to rheumatoid arthritis and polymyalgia rheumatica ${ }^{99,100}$. In addition, Wang et al. also reported compound genotype RANTES-403 A/A, -28 $\mathrm{C} / \mathrm{G}$ more common in Chinese patients with rheumatoid arthritis ${ }^{99}$. On the other hand, RANTES-403 A/G SNP affects neither the susceptibility to breast cancer nor presence of metastases ${ }^{37}$.

\section{CCR5}

\subsection{Biological function of CCR5}

The CC receptor 5 mediates chemotaxis after the interaction with its ligands CCL3, CCL4, CCL5 and $\mathrm{CCL}^{1,64}$. CCR5 is presented by activated/memory Th 1 lymphocytes, macrophages, peripheral blood-derived dendritic cells, endothelial cells, epithelium, vascular smooth muscle, and fibroblasts. CCR5 expression was also reported in CD $34^{+}$hematopoietic progenitor cells, Langerhans' cells, neurons, astrocytes, and thymocytes ${ }^{1,43}$.

\subsection{CCR5 gene and its polymorphisms}

CC chemokine receptor 5 is localized on chromosome 3p21.3-p2499. In the CCR5 gene, open reading frame (ORF) 32 base pair deletion CCR $5 \Delta 32$ creates a trun- cated protein that fails to reach the cell surface. This most studied polymorphism is present in various Caucasian populations at a frequency of about $9 \%$, while it is almost absent in some African, Japanese and Chinese ethnic groups ${ }^{101,102}$. Among European white populations there is a north to south gradient of the prevalence of the deletion allele, with allelic frequencies highest in Denmark and Northern France and lowest in Corsica ${ }^{103}$.

CCR5 expression may be regulated by the broad spectrum of polymorphisms located in either upstream promoter or downstream promoter, which includes the "intronic" region between exons 1 and 3. In this context, sequence analysis of CCR5 cis-regulatory region (-2761 to $-1835)$ revealed 32 variable sites that define 27 unique human haplotypes. Based on 7 polymorphisms (-2733 A/G, -2554 G/T, -2459 G/A, -2135 T/C, -2132 C/T, -2086 A/G, and $-1835 \mathrm{C} / \mathrm{T}) 7$ distinct clusters of these haplotypes were designated as CCR5 human haplogroups (HH)-A, $-\mathrm{B},-\mathrm{C},-\mathrm{D},-\mathrm{E},-\mathrm{F}$, and $-\mathrm{G}^{104}$. The CCR5 haplogroups also involve haplotype $\mathrm{P} 1\left(208^{*} \mathrm{G}, 612^{*} \mathrm{~A}, 626^{*} \mathrm{C}, 627^{*} \mathrm{C}\right.$, $\left.630 * \mathrm{C}, 647^{*} \mathrm{C}, 676^{*} \mathrm{~A}, 684^{*} \mathrm{~T}, 714^{*} \mathrm{C}, 811^{*} \mathrm{G}\right)$ that is in linkage disequilibrium with CCR5 $\Delta 32$ and CCR2-64I ${ }^{106}$. Similarly CCR5 haplotypes in haplogroups F (HHF*2) and $\mathrm{G}\left(\mathrm{HHG}^{*} 2\right)$ are associated with CCR2-64I and CCR5 532 polymorphisms, respectively ${ }^{104}$.

Considering CCR5 expression, Hladik et al. reported reduced CCR5 densities on both T-helper cells and monocytes with haplotypes CCR5 $32 / \mathrm{CCR} 5-2459 * \mathrm{~A}$ (in complete linkage disequilibrium) and CCR5 wt/CCR5$2459 * \mathrm{G}^{7}$. Further CCR5-2459*A homozygosity correlates with increased number of CD4+ cells expressing CCR5 in individuals without CCR5 32 and CCR2-64I. Furthermore CCR5-2459*A allele is in complete linkage disequilibrium with CCR5-59653* $\mathrm{T}^{105}$.

\subsection{Diseases associated with CCR5 polymorphisms}

\subsubsection{Atherosclerosis and myocardial infarction (MI)}

CCR5 32 increases the risk for abdominal aortic aneurysm (AAA) ${ }^{107}$. In addition, it could be a useful factor that differentiates AAA from both peripheral arterial occlusive disease and carotid stenosis as well as from ruptured AAA. In this context, the homozygotes for rare deletion have more than four-fold higher risk for ruptured AAA than electively repaired $\mathrm{AAA}^{105}$. On the other hand, Gonzalez et al. found that Spanish males carrying the CCR5 532 allele are protected against an early episode of $\mathrm{MI}^{55}$. In agreement with this, Szalai et al. suggested that the homozygotes for CCR5 32 are protected against heart disease because they found no homozygotes for CCR5 $\Delta 32$ in CAD patients but six in the control group ${ }^{15}$. However, there was no difference in CCR $5 \Delta 32$ allele distribution between patients and controls. This relationship between CAD and CCR5 32 was not observed in a German study ${ }^{16}$ as well as in Czech males, who had their first MI before the age of 55 years ${ }^{108}$. In addition, CCR $5 \Delta 32$ can increase the degree of calcification in specific conditions ${ }^{109}$. 


\subsubsection{Multiple sclerosis (MSc)}

$\mathrm{T}$ cells expressing CCR5 are increased in the blood of patients with multiple sclerosis ${ }^{1}$. More importantly, perivascular space and nearby microglia are also infiltrated by CCR 5 positive cells. In addition, antagonists to this receptor could be useful for treating of $\mathrm{MS}^{60}$. These findings suggest that altered CCR5 expression could modulate MS.

This is in agreement with an immunogenetic study that reported, approximately, 3 years later MSc onset in patients carrying CCR $5 \Delta 32^{62}$. CCR 5 deletion allele may also be considered as a favourable prognostic factor in MS, based on percentage of patients who reached EDSS (Expanded Disability Status Scale) ${ }^{110}$. Furthermore, Sellebjerg et al. found that CCR5 32 is associated with lower risk of recurrent clinical disease activity ${ }^{111}$. In other studies, however, the deletion affected neither disease severity $^{112,113}$, nor age of MSc onset ${ }^{110,113}$. In some cases, indeed, CCR5 $\Delta 32$ was associated with earlier age of MSc onset $^{111,112}$. CCR5 32 mutation was observed to be also associated with MSc in HLA-DR4-positive Russians ${ }^{114}$. A more recent study only admitted that CCR $5 \Delta 32$ has a dose effect on CCR5 expression in the central nervous system, because CCR $5 \Delta 32$ homozygotes contained no CCR5 positive T-cells in lesions and periplaque white matter, whereas heterozygous patients had reduced CCR5 expression compared to wild type patients. On the other hand, there was no difference in the density of macrophages/microglia stratified according to CCR5 32 genotype and demyelinating stage ${ }^{113}$. These data indicate that CCR5 expression is not essential for the development of MS.

\subsubsection{Rheumatoid arthritis $(R A)$ and related diseases}

The CCR $5 \Delta 32$ is a genetic marker related to the severity of $\mathrm{RA}^{115}$. Recent study provides further evidence for a protective effect of the CCR $5 \Delta 32$ variant on rheumatoid arthritis in a New Zealand cohort ${ }^{116}$. In Slovak Caucasians, carrier status for the CCR5 32 allele may also contribute to protection from the development of primary Sjogren's syndrome ${ }^{117}$.

\subsubsection{Lung diseases}

Petrek et al. reported that CCR5 32 allele is associated with susceptibility to sarcoidosis in the Czech population ${ }^{58}$. In addition, because it was present in $39 \%$ of patients requiring corticosteroids but only in $17 \%$ patients who did not need therapeutic intervention, the authors related this CCR5 deletion allele to the more advance disease $^{58}$. Besides CCR5 32 polymorphism, a recent study explored the distribution of a further seven SNPs (at positions $-2459,-2135,-2086,-1835,-5663,-3900$, and -3458) in Dutch and British patients with sarcoidosis. In both populations, CCR5 haplotype HHC was overrepresented among sarcoidosis patients with radiographic stages II and higher versus stages 0 and I. Furthermore, the carriers of CCR5 haplotype $\mathrm{HHC}$ were associated with a lower number of pulmonary function tests and BAL neutrophilia ${ }^{118}$.

CCL5/CCR5 mediated chemotaxis may favourably affect the bias of Th2 immune response of asthma by induction Th lymphocytes with Th 1 phenotype. By contrast, Hall et al. found that individuals carrying CCR $5 \Delta 32$ are at reduced risk of developing asthma ${ }^{119}$. Subsequently two studies failed to show any association of this polymorphism with asthma or disease severity ${ }^{120,121}$. Furthermore, a transmission disequilibrium test showed similar results for susceptibility to atopy or wheeze ${ }^{120}$.

\subsubsection{HIV infection}

Along with the CD4 receptor, CCR5 is utilized as a major HIV co-receptor for entry of macrophage-tropic, non-SI (NSI) HIV-1 variants (called R5) into the cells ${ }^{122}$. According to current hypotheses, the homozygotes for CCR $5 \Delta 32$ have nearly complete resistance to HIV-1 infection despite repeated exposure, and HIV-1 infected heterozygotes for CCR5 $\Delta 32$ delay the onset of acquired immunodeficiency syndrome (AIDS) ${ }^{123}$

By contrast to the above-mentioned CCR5 32 deletion, homozygotes for the haplotype P1 are associated with rapid progression to AIDS in both Caucasian and African-American populations ${ }^{106,123,124,125}$. Both CCR5 32 and CCR 5 P1 have a strong influence early in HIV-1 infection ${ }^{126}$. When homozygosity for haplotype P1 occurs in individuals that are also heterozygous for protective CCR5 32 and CCR2-64I, their effects are offset by each other ${ }^{106}$. Further, the haplotype P1 was found to be in a complete linkage disequilibrium with CCR5-2459*A allele (CCR5-2459 A/G SNP) ${ }^{124,125}$. CCR5-2459 A/A individuals progress to AIDS faster than $G / G$ individuals in the absence of the CCR5 32 and CCR2-64I ${ }^{7,127,128,129}$. In addition, recent results indicate that inheritance of the CCR5 332 /wt plus CCR5-2459 A/G genotype combination may reduce target cell susceptibility to HIV-17. Furthermore, P1 haplotype and CCR5-2459*A allele form part of the haplogroup HHE $\left(-2459 * \mathrm{~A}\right.$ and $-2135^{*} \mathrm{C}$ but lacking $-2733^{*} \mathrm{G}$ and $\left.-1835^{*} \mathrm{~T}\right)$ that has been reported to be associated with rapid AIDS progression ${ }^{130}$.

\subsubsection{Diabetes mellitus}

CCR5 32 predispose to later onset of type 1 diabetes mellitus ${ }^{131}$. A subsequent study found the relationship of both CCR5 $\Delta 32$ and CCR5-2459*G allele with developing diabetic nephropathy, but only in males. In addition, the haplotypes with at least one risk allele (CCR5 32 or CCR5-2459*G allele) remained associated with diabetic nephropathy, whereas the haplotype containing CCR5$2459 * A$ and lack of CCR $5 \Delta 32$ allele had protective effects on disease susceptibility ${ }^{132}$. By contrast, CCR5-2459*A allele was suggested to be an independent risk factor for diabetic nephropathy in patients with type 2 diabetes $^{133}$.

\subsubsection{Hepatitis $C$ and hepatitis $B$ infection}

Promrat and Liang outlined the role of polymorphisms of the genes for CCR5, CCR2 and their ligands in HCV susceptibility and disease prognosis ${ }^{96}$. In this context, they discussed the relevance of studies that reported higher frequency of CCR $5 \Delta 32$ in HCV infected haemophiliacs ${ }^{134}$ or in a subgroup of HIV exposed nonpositive individuals ${ }^{135}$. A subsequent study failed to find any association of CCR $5 \Delta 32$ with $\mathrm{HCV}$ infection ${ }^{96}$. On 
the other hand, heterozygotes for CCR5 32 were shown to be associated with spontaneous hepatitis $\mathrm{C}$ viral clearance and lower hepatic inflammation scores in women ${ }^{71}$. In agreement with this, Hellier et al. found an association between CCR5 32 and reduced portal inflammation and milder fibrosis in large European cohort ${ }^{72}$. Considering HBV infection, the CCR5-2459*A allelic genotype was associated with an increased risk of chronic infection rather than spontaneous clearance, and the presence of the CCR5-2459* G allele was associated with the spontaneous clearance of $\mathrm{HBV}^{136}$.

\subsubsection{Transplantation}

There are two studies that investigated the influence of CCR5 polymorphisms on outcome of cardiac transplantation. Fildes et al. found that CCR5 32 in cardiac graft donor is associated with favourable effects on survival following heart transplantation in patients transplanted for a non-ischemic condition ${ }^{137}$. However, they found no correlation between recipient genotype and outcome of transplantation. On the other hand, Simeoni et al. reported that subjects with transplanted heart carrying both the CCR5 haplotype E and the RANTES-403*A allele are at increased risk of developing of delayed heart graft rejection ${ }^{69}$. Consistently, the renal graft recipients with CCR5-2459 A/A genotype were found to have reduced risk of acute renal graft rejection ${ }^{70}$. On the other hand, the CCR5-2459*A allele is more prevalent in donor kidney that experienced acute cellular rejection, acute rejection or biopsy/proven chronic allograft nephropathy ${ }^{138}$. Furthermore, CCR5-2459 A/G influences neither the incidence of acute liver rejection nor long-term allograft survival after liver transplantation ${ }^{39}$. There were no differences in the incidence of acute renal graft rejection among patients stratified as with or without CCR $5 \Delta 32^{70}$. CCR5 32 is a risk factor for the development of ischemictype biliary lesions after liver transplantation and leads to the reduction in 5 -year survival ${ }^{139}$. This relationship between CCR5 32 and liver graft survival or risk for liver acute rejection was not reported in previous study ${ }^{68}$.

\subsubsection{Systemic lupus erythematosus (SLE)}

CCR5 32 was not involved in susceptibility to SLE in a Spanish population, although this polymorphism correlates with the development of lupus nephritis in Spanish patients with SLE ${ }^{140}$.

\subsubsection{Other diseases}

Singh et al. showed that the heterozygotes for CCR5 32 have less neurocognitive impairment in cohort of children with symptomatic HIV-1 infection ${ }^{129}$.

In a Turkish population heterozygotes for CCR $5 \Delta 32$ are at higher risk for the development of breast cancer as well as laryngeal, thyroid and brain carcinomas ${ }^{141}$. Another study fail to find any association between CCR5 32 or CCR5-2459 A/G and breast cancer ${ }^{73}$. By contrast, CCR5 32 is protective factor against AIDS related nonHodgkin's lymphoma, but it is not associated with risk for Kaposi's sarcoma ${ }^{142}$.
In 2001 Hampe et al. suggested the existence of inflammatory bowel disease (IBD) susceptibility gene on the proximal part of chromosome $3 \mathrm{p}^{74}$. However, it is unlikely that the CCR5 $\Delta 32$ allele is an important marker for predisposition to $\mathrm{IBD}^{74,75}$.

\section{CONCLUSION}

Several studies provide evidence of the susceptibility of gene profile of CCL2/CCL5 and CCR2/CCR5 that promotes deregulation of leukocyte trafficking leading to disease progression or higher risk of disease onset. Furthermore, both chemokine receptors are utilised by HIV as co-receptors for cell entry and their several variants have been showed to modulate susceptibility to HIV infection. Recent data also suggest that screening for CCL2/CCL5 and CCR2/CCR5 polymorphisms can be useful for forecasting transplantation outcome and the process of metastasis. However, further work is needed to explain inconsistent results among similarly designed studies. For example, recent advances in the identification of linkage disequilibrium between gene variants provide opportunity for other large case-control studies. However, rare incidence or suboptimal definition of some diseases remain restrictive factors. Further challenges arise from the heterogeneity of disease progression markers. We also need more information about posttranscriptional events to understand functional relevance of polymorphisms and to discovery new avenues to blocking disease development.

\section{ACKNOWLEDGEMENTS}

This study was supported by Grant Agency of Czech Republic (No. 310/05/2614) and Czech Ministry of Health (IGA MZ CR NR/9037). Prof. MUDr. M. Petrek, CSc., MUDr. F. Mrazek, Ph.D. and Dr. E. Kriegova are thanked for helpful comments.

\section{REFERENCES}

1. Yoshie O, Imai T, Nomiyama H. Chemokines in immunity. Adv Immunol. 2001; 78:57-110.

2. Mackay CR. Chemokines: what chemokine is that? Curr Biol. 1997; 7:384-6.

3. Charo IF, Taubman MB. Chemokines in the pathogenesis of vascular disease. Circ Res. 2004; 95:858-66.

4. McDermott DH, Yang Q, Kathiresan S, Cupples LA, Massaro JM, Keaney JF Jr et al. CCL2 polymorphisms are associated with serum monocyte chemoattractant protein-1 levels and myocardial infarction in the Framingham Heart Study. Circulation. 2005; 112: 1113-20.

5. Liu H, Shioda T, Nagai Y, Iwamoto A, Wasi C, Ma J et al. Distribution of HIV-1 disease modifying regulated on activation normal T cell expressed and secreted haplotypes in Asian, African and Caucasian individuals. French ALT and IMMUNOCO Study Group. AIDS. 1999; 13:2602-3.

6. An P, Nelson GW, Wang L, Donfield S, Goedert JJ, Phair J et al. Modulating influence on HIV/AIDS by interacting RANTES gene variants. Proc Natl Acad Sci U S A. 2002; 99:10002-7. 
7. Hladik F, Liu H, Speelmon E, Livingston-Rosanoff D, Wilson S, Sakchalathorn P et al. (2005) Combined effect of CCR5-Delta32 heterozygosity and the CCR 5 promoter polymorphism $-2459 \mathrm{~A} / \mathrm{G}$ on CCR5 expression and resistance to human immunodeficiency virus type 1 transmission. J Virol. 2005; 79:11677-84.

8. Arndt PG, Suzuki N, Avdi NJ, Malcolm KC, Worthen GS. Lipopolysaccharide-induced c-Jun NH2-terminal kinase activation in human neutrophils: role of phosphatidylinositol 3-Kinase and Syk-mediated pathways. J Biol Chem. 2004; 279:10883-91.

9. Lee YW, Eum SY, Chen KC, Hennig B, Toborek M. Gene expression profile in interleukin-4-stimulated human vascular endothelial cells. Mol Med. 2004; 10:19-27.

10. Distler O, Pap T, Kowal-Bielecka O, Meyringer R, Guiducci S, Landthaler $\mathrm{M}$ et al. Overexpression of monocyte chemoattractant protein 1 in systemic sclerosis: role of platelet-derived growth factor and effects on monocyte chemotaxis and collagen synthesis. Arthritis Rheum. 2001; 44:2665-78.

11. Mestdagt M, Polette M, Buttice G, Noel A, Ueda A, Foidart JM et al. Transactivation of MCP-1/CCL2 by beta-catenin/TCF-4 in human breast cancer cells. Int J Cancer. 2006; 118:35-42.

12. Jost MM, Ninci E, Meder B, Kempf C, Van Royen N, Hua J et al. Divergent effects of GM-CSF and TGFbetal on bone marrowderived macrophage arginase-1 activity, MCP-1 expression, and matrix metalloproteinase-12: a potential role during arteriogenesis. FASEB J. 2003; 17:2281-3.

13. Mehrabian M, Sparkes RS, Mohandas T, Fogelman AM, Lusis AJ. Localization of monocyte chemotactic protein-1 gene (SCYA2) to human chromosome 17q11.2-q21.1. Genomics. 1991; 9:200-3.

14. Rollins BJ, Morton CC, Ledbetter DH, Eddy R.L, Shows TB Assignment of the human small inducible cytokine A2 gene, SCYA2 (encoding JE or MCP-1), to 17q11.2-12: evolutionary relatedness of cytokines clustered at the same locus. Genomics 1991; 10:489-92.

15. Szalai C, Duba J, Prohaszka Z, Kalina A, Szabo T, Nagy B et al. Involvement of polymorphisms in the chemokine system in the susceptibility for coronary artery disease (CAD). Coincidence of elevated $\mathrm{Lp}(\mathrm{a})$ and MCP-1 -2518 G/G genotype in CAD patients. Atherosclerosis. 2001; 158:233-9.

16. Simeoni E, Winkelmann BR, Hoffmann MM, Fleury S, Ruiz J, Kappenberger L et al. Association of RANTES G-403A gene polymorphism with increased risk of coronary arteriosclerosis. Eur Heart J. 2004; 25:1438-46.

17. Flex A, Gaetani E, Papalo P, Straface G, Proia AS, Pecorini G et al. Proinflammatory Genetic Profiles in Subjects With History of Ischemic Stroke. Stroke. 2004; 35:2270.

18. Bjarnadottir K, Eiriksdottir G, Aspelund T, Gudnason V. Examination of genetic effects of polymorphisms in the MCP-1 and CCR2 genes on MI in the Icelandic population. Atherosclerosis. 2005

19. A genome-wide search for asthma susceptibility loci in ethnically diverse populations. The Collaborative Study on the Genetics of Asthma (CSGA). Nat Genet. 1997; 15:389-92.

20. Szalai C, Kozma GT, Nagy A, Bojszko A, Krikovszky D, Szabo T et al. A. Polymorphism in the gene regulatory region of MCP-1 is associated with asthma susceptibility and severity. J Allergy Clin Immunol. 2001; 108:375-81

21. Kozma GT, Falus A, Bojszko A, Krikovszky D, Szabo T, Nagy A et al. Lack of association between atopic eczema/dermatitis syndrome and polymorphisms in the promoter region of RANTES and regulatory region of MCP-1. Allergy. 2002; 57:160-3.

22. Takada T, Suzuki E, Morohashi K, Omori K, Gejyo F. MCP-1 and MIP-1A gene polymorphisms in Japanese patients with sarcoidosis Intern Med. 2002; 41:813-8.

23. Kroner A, Maurer M, Loserth S, Kleinschnitz C, Hemmer B, Rosche B et al. Analysis of the monocyte chemoattractant protein $1-2518$ promoter polymorphism in patients with multiple sclerosis. Tissue Antigens. 2004; 64:70-3.

24. Karrer S, Bosserhoff AK, Weiderer P, Distler O, Landthaler M, Szeimies RM et al. The -2518 promotor polymorphism in the MCP1 gene is associated with systemic sclerosis. J Invest Dermatol. $2005 ; 124: 92-8$.
25. Gonzalez-Escribano MF, Torres B, Aguilar F, Rodriguez R, Garcia A, Valenzuela A et al. MCP-1 promoter polymorphism in Spanish patients with rheumatoid arthritis. Hum Immunol. 2003; 64:7414.

26. Lee YH, Kim HJ, Rho YH, Choi SJ, Ji JD, Song GG. Functional polymorphisms in matrix metalloproteinase-1 and monocyte chemoattractant protein-1 and rheumatoid arthritis. Scand J Rheumatol. 2003; 32:235-9.

27. Gonzalez E, Rovin BH, Sen L, Cooke G, Dhanda R, Mummidi S et al. (2002) HIV-1 infection and AIDS dementia are influenced by a mutant MCP-1 allele linked to increased monocyte infiltration of tissues and MCP-1 levels. Proc Natl Acad Sci U S A. 2002; 99: 13795-800.

28. Letendre S, Marquie-Beck J, Singh KK, de Almeida S, Zimmerman $\mathrm{J}$, Spector SA et al. The monocyte chemotactic protein-1 -2578G allele is associated with elevated MCP-1 concentrations in cerebrospinal fluid. J Neuroimmunol. 2004; 157:193-6.

29. Frade JM, Llorente M, Mellado M, Alcami J, Gutierrez-Ramos $\mathrm{JC}$, Zaballos A et al. The amino-terminal domain of the CCR2 chemokine receptor acts as coreceptor for HIV-1 infection. J Clin Invest. 1997; 100:497-502.

30. Cinque P, Vago L, Mengozzi M, Torri V, Ceresa D, Vicenzi E et al. Elevated cerebrospinal fluid levels of monocyte chemotactic protein-1 correlate with HIV-1 encephalitis and local viral replication AIDS. 1998; 12:1327-32.

31. Eugenin EA, Osiecki K, Lopez L, Goldstein H, Calderon TM, Berman JW. CCL2/monocyte chemoattractant protein-1 mediates enhanced transmigration of human immunodeficiency virus (HIV)-infected leukocytes across the blood-brain barrier: a potential mechanism of HIV-CNS invasion and NeuroAIDS. J Neurosci. 2006; 26:1098-106.

32. Singh KK, Ellis RJ, Marquie-Beck J, Letendre S, Heaton RK, Grant I et al. CCR2 polymorphisms affect neuropsychological impairment in HIV-1-infected adults. J Neuroimmunol. 2004; 157: 185-92.

33. Modi WS, Goedert JJ, Strathdee S, Buchbinder S, Detels R, Donfield S et al. MCP-1-MCP-3-Eotaxin gene cluster influences HIV-1 transmission. AIDS. 2003; 17:2357-65.

34. Kim HL, Lee DS, Yang SH, Lim CS, Chung JH, Kim S et al. The polymorphism of monocyte chemoattractant protein-1 is associated with the renal disease of SLE. Am J Kidney Dis. 2002; 40:1146-52.

35. Tucci M, Barnes EV, Sobel ES, Croker BP, Segal MS, Reeves WH et al. Strong association of a functional polymorphism in the monocyte chemoattractant protein 1 promoter gene with lupus nephritis. Arthritis Rheum. 2004; 50:1842-9.

36. Simeoni E, Hoffmann MM, Winkelmann BR, Ruiz J, Fleury S, Boehm BO et al. Association between the A-2518G polymorphism in the monocyte chemoattractant protein-1 gene and insulin resistance and Type 2 diabetes mellitus. Diabetologia. 2004; 47:157480.

37. Ghilardi G, Biondi ML, La Torre A, Battaglioli L, Scorza R. Breast cancer progression and host polymorphisms in the chemokine system: role of the macrophage chemoattractant protein-1 (MCP-1) -2518 G allele. Clin Chem. 2005; 51:452-5.

38. Kruger B, Schroppel B, Ashkan R, Marder B, Zulke C, Murphy B et al. A Monocyte chemoattractant protein-1 (MCP-1) polymorphism and outcome after renal transplantation. J Am Soc Nephrol. 2002; 13:2585-9.

39. Schroppel B, Fischereder M, Lin M, Marder B, Schiano T, Kramer BK et al. Analysis of gene polymorphisms in the regulatory region of MCP-1, RANTES, and CCR5 in liver transplant recipients. J Clin Immunol. 2002; 22:381-5.

40. Muhlbauer M, Bosserhoff AK, Hartmann A, Thasler WE, Weiss TS, Herfarth $\mathrm{H}$ et al. A novel MCP-1 gene polymorphism is associated with hepatic MCP-1 expression and severity of HCV-related liver disease. Gastroenterology. 2003; 125:1085-93.

41. Glas J, Torok HP, Tonenchi L, Schiemann U, Folwaczny C. The -2518 promotor polymorphism in the MCP-1 gene is not associated with liver cirrhosis in chronic hepatitis $\mathrm{C}$ virus infection. Gastroenterology. 2004; 126:1930-1. 
42. Pola R, Flex A, Gaetani E, Proia AS, Papaleo P, Giorgio AD et al Monocyte chemoattractant protein-1 (MCP-1) gene polymorphism and risk of Alzheimer's disease in Italians. Exp Gerontol. 2004; 39:1249-52.

43. Murphy PM, Baggiolini M, Charo IF, Hebert CA, Horuk R, Matsushima $\mathrm{K}$ et al. International union of pharmacology. XXII. Nomenclature for chemokine receptors. Pharmacol Rev. 2000; 52:145-76.

44. Valentonyte R, Hampe J, Croucher PJ, Muller-Quernheim J, Schwinger E, Schreiber S et al. Study of C-C chemokine receptor 2 alleles in sarcoidosis, with emphasis on family-based analysis. Am J Respir Crit Care Med. 2005; 171:1136-41.

45. Smith MW, Dean M, Carrington M, Winkler C, Huttley GA, Lomb DA et al. Contrasting genetic influence of CCR2 and CCR5 variants on HIV-1 infection and disease progression. Hemophilia Growth and Development Study (HGDS), Multicenter AIDS Cohort Study (MACS), Multicenter Hemophilia Cohort Study (MHCS), San Francisco City Cohort (SFCC), ALIVE Study. Science. 1997; 277:959-65.

46. Anzala AO, Ball TB, Rostron T, O'Brien SJ, Plummer FA, RowlandJones SL. CCR2-64I allele and genotype association with delayed AIDS progression in African women. University of Nairobi Collaboration for HIV Research. Lancet. 1998; 351:1632-3.

47. Struyf F, Thoelen I, Charlier N, Keyaerts E, Van der Donck I et al. Prevalence of CCR5 and CCR2 HIV-coreceptor gene polymorphisms in Belgium. Hum Hered. 2000; 50:304-7.

48. Lewandowska M, Franciszkiewicz K, Prokop J, Ofori H, Jagodzinski PP. Distribution of two HIV-1-resistant polymorphisms (SDF1-3'A and CCR2-64I alleles) in the Polish population. J Hum Genet. 2002; 47:585-9.

49. Nakayama EE, Tanaka Y, Nagai Y, Iwamoto A, Shioda T. A CCR2V64I polymorphism affects stability of CCR2A isoform. AIDS. 2004; 18:729-38.

50. Lee B, Doranz BJ, Rana S, Yi Y, Mellado M, Frade JM et al. Influence of the CCR2-V64I polymorphism on human immunodeficiency virus type 1 coreceptor activity and on chemokine receptor function of CCR2b, CCR3, CCR5, and CXCR4. J Virol. 1998; 72, $7450-8$

51. Mariani R, Wong S, Mulder LC, Wilkinson DA, Reinhart AL, LaRosa G et al. CCR2-64I polymorphism is not associated with altered CCR5 expression or coreceptor function. J Virol. 1999; 73: 2450-9.

52. Sabbe R, Picchio GR, Pastore C, Chaloin O, Hartley O, Offord R et al. Donor- and ligand-dependent differences in C-C chemokine receptor 5 reexpression. J Virol. 2001; 75:661-71.

53. Ortlepp JR, Krantz C, Kimmel M, von Korff A, Vesper K, Schmitz F et al. Additive effects of the chemokine receptor 2, vitamin D receptor, interleukin-6 polymorphisms and cardiovascular risk factors on the prevalence of myocardial infarction in patients below 65 years. Int J Cardiol. 2005; 105:90-5.

54. Petrkova J, Cermakova Z, Drabek J, Lukl J, Petrek M. CC chemokine receptor (CCR) 2 polymorphism in Czech patients with myocardial infarction. Immunol Lett. 2003; 88:53-5.

55. Gonzalez P, Alvarez R, Batalla A, Reguero JR, Alvarez V, Astudillo A et al. Genetic variation at the chemokine receptors CCR5/CCR2 in myocardial infarction. Genes Immun. 2001; 2:191-5.

56. Valdes AM, Wolfe ML, O'Brien EJ, Spurr NK, Gefter W, Rut A et al. Val64Ile polymorphism in the C-C chemokine receptor 2 is associated with reduced coronary artery calcification. Arterioscler Thromb Vasc Biol. 2002; 22:1924-8.

57. Hizawa N, Yamaguchi E, Furuya K, Jinushi E, Ito A, Kawakami Y. The role of the C-C chemokine receptor 2 gene polymorphism V64I (CCR2-64I) in sarcoidosis in a Japanese population. Am J Respir Crit Care Med. 1999; 159:2021-3.

58. Petrek M, Drabek J, Kolek V, Zlamal J, Welsh KI, Bunce M et al. $\mathrm{CC}$ chemokine receptor gene polymorphisms in Czech patients with pulmonary sarcoidosis. Am J Respir Crit Care Med. 2000; 162:1000-3.

59. Spagnolo P, Renzoni EA, Wells AU, Sato H, Grutters JC, Sestini $P$ et al. C-C chemokine receptor 2 and sarcoidosis: association with Lofgren's syndrome. Am J Respir Crit Care Med. 2003; 168: 11626.
60. Ubogu EE, Cossoy MB, Ransohoff RM. The expression and function of chemokines involved in CNS inflammation. Trends Pharmacol Sci. 2006; 27:48-55.

61. Miyagishi R, Niino M, Fukazawa T, Yabe I, Kikuchi S, Tashiro K. (2003) C-C chemokine receptor 2 gene polymorphism in Japanese patients with multiple sclerosis. J Neuroimmunol. 145:135-8.

62. Barcellos LF, Schito AM, Rimmler JB, Vittinghoff E, Shih A, Lincoln R et al. (2000) CC-chemokine receptor 5 polymorphism and age of onset in familial multiple sclerosis. Multiple Sclerosis Genetics Group. Immunogenetics. 51:281-8.

63. van Rij RP, de Roda Husman AM, Brouwer M, Goudsmit J, Coutinho RA, Schuitemaker H. (1998) Role of CCR2 genotype in the clinical course of syncytium-inducing (SI) or non-SI human immunodeficiency virus type 1 infection and in the time to conversion to SI virus variants. J Infect Dis. 178:1806-11.

64. Liu H, Hwangbo Y, Holte S, Lee J, Wang C, Kaupp N et al. Analysis of genetic polymorphisms in CCR5, CCR2, stromal cellderived factor-1, RANTES, and dendritic cell-specific intercellular adhesion molecule-3-grabbing nonintegrin in seronegative individuals repeatedly exposed to HIV-1. J Infect Dis. 2004; 190:1055-8.

65. Ioannidis JP, Rosenberg PS, Goedert JJ, Ashton LJ, Benfield TL, Buchbinder SP et al. International Meta-Analysis of HIV Host Genetics. Effects of CCR5-Delta32, CCR2-64I, and SDF-1 3'A alleles on HIV-1 disease progression: An international meta-analysis of individual-patient data. Ann Intern Med. 2001; 135:782-95.

66. Mummidi S, Ahuja SS, Gonzalez E, Anderson SA, Santiago EN, Stephan KT et al. Genealogy of the CCR5 locus and chemokine system gene variants associated with altered rates of HIV-1 disease progression. Nat Med. 1998; 4:786-93

67. Shrestha S, Strathdee SA, Galai N, Oleksyk T, Fallin MD, Mehta $\mathrm{S}$ et al. Behavioral risk exposure and host genetics of susceptibility to HIV-1 infection. J Infect Dis. 2006; 193:16-26.

68. Schroppel B, Fischereder M, Ashkar R, Lin M, Kramer BK, Mardera B et al. The impact of polymorphisms in chemokine and chemokine receptors on outcomes in liver transplantation. Am J Transplant. 2002; 2:640-5.

69. Simeoni E, Vassalli G, Seydoux C, Ramsay D, Noll G, von Segesser LK et al. CCR5, RANTES and CX3CR1 polymorphisms: possible genetic links with acute heart rejection. Transplantation. 2005; $80: 1309-15$.

70. Abdi R, Tran TB, Sahagun-Ruiz A, Murphy PM, Brenner BM, Milford EL et al. rejection in human renal transplantation. J Am Soc Nephrol. 2002; 13:754-8.

71. Goulding C, McManus R, Murphy A, MacDonald G, Barrett S, Crowe $\mathrm{J}$ et al. The CCR5-delta32 mutation: impact on disease outcome in individuals with hepatitis $\mathrm{C}$ infection from a single source. Gut. 2005; 54:1157-61.

72. Hellier S, Frodsham AJ, Hennig BJ, Klenerman P, Knapp S, Ramaley $\mathrm{P}$ et al. Association of genetic variants of the chemokine receptor CCR5 and its ligands, RANTES and MCP-2, with outcome of HCV infection. Hepatology. 2003; 38:1468-76.

73. Zafiropoulos A, Crikas N, Passam AM, Spandidos DA. Significant involvement of CCR2-64I and CXCL12-3a in the development of sporadic breast cancer. J Med Genet. 2004; 41:59.

74. Hampe J, Lynch NJ, Daniels S, Bridger S, Macpherson AJ, Stokkers $\mathrm{P}$ et al. Fine mapping of the chromosome $3 \mathrm{p}$ susceptibility locus in inflammatory bowel disease. Gut. 2001; 48:191-7.

75. Rector A, Vermeire S, Thoelen I, Keyaerts E, Struyf F, Vlietinck R et al. Analysis of the CC chemokine receptor 5 (CCR5) delta-32 polymorphism in inflammatory bowel disease. Hum Genet. 2001; 108:190-3.

76. Duggal P, Winkler CA, An P, Yu XF, Farzadegan H, O’Brien SJ et al. The effect of RANTES chemokine genetic variants on early HIV-1 plasma RNA among African American injection drug users. J Acquir Immune Defic Syndr. 2005; 38:584-9.

77. Boger CA, Fischereder M, Deinzer M, Aslanidis C, Schmitz G, Stubanus $\mathrm{M}$ et al. RANTES gene polymorphisms predict all-cause and cardiac mortality in type 2 diabetes mellitus hemodialysis patients. Atherosclerosis. 2005; 183:121-9.

78. Gade-Andavolu R, Comings DE, MacMurray J, Vuthoori RK, Tourtellotte WW, Nagra RM et al. RANTES: a genetic risk marker for multiple sclerosis. Mult Scler. 2004; 10:536-9. 
79. Koppelman GH, Stine OC, Xu J, Howard TD, Zheng SL, Kauffman HF et al. Genome-wide search for atopy susceptibility genes in Dutch families with asthma. J Allergy Clin Immunol. 2002; 109:498-506.

80. Fryer AA, Spiteri MA, Bianco A, Hepple M, Jones PW, Strange RC et al. The - $403 \mathrm{G}->$ A promoter polymorphism in the RANTES gene is associated with atopy and asthma. Genes Immun. 2000; 1:509-14.

81. Al-Abdulhadi SA, Helms PJ, Main M, Smith O, Christie G. Preferential transmission and association of the $-403 \mathrm{G} \rightarrow$ A promoter RANTES polymorphism with atopic asthma. Genes Immun. 2005; 6:24-30.

82. Yao TC, Kuo ML, See LC, Chen LC, Yan DC, Ou LS et al. The RANTES promoter polymorphism: a genetic risk factor for nearfatal asthma in Chinese children. J Allergy Clin Immunol. 2003; 111:1285-92.

83. Hizawa N, Yamaguchi E, Konno S, Tanino Y, Jinushi E, Nishimura M. A functional polymorphism in the RANTES gene promoter is associated with the development of late-onset asthma. Am J Respir Crit Care Med. 2002; 166:686-90.

84. Moissidis I, Chinoy B, Yanamandra K, Napper D, Thurmon T, Bocchini J Jr et al. Association of IL-13, RANTES, and leukotriene $\mathrm{C} 4$ synthase gene promoter polymorphisms with asthma and/or atopy in African Americans. Genet Med. 2005; 7:406-10.

85. Petrek M, Kolek V, Szotkowska J, du Bois RM. CC and C chemokine expression in pulmonary sarcoidosis. Eur Respir J. 2002; 20:1206-12.

86. Takada T, Suzuki E, Ishida T, Moriyama H, Ooi H, Hasegawa T et al. Polymorphism in RANTES chemokine promoter affects extent of sarcoidosis in a Japanese population. Tissue Antigens. 2001; 58:293-8.

87. Gonzalez E, Dhanda R, Bamshad M, Mummidi S, Geevarghese $\mathrm{R}$, Catano $\mathrm{G}$ et al. Global survey of genetic variation in CCR5, RANTES, and MIP-1alpha: impact on the epidemiology of the HIV-1 pandemic. Proc Natl Acad Sci U S A. 2001; 98:5199-204.

88. Zhao XY, Lee SS, Wong KH, Chan KC, Ma S, Yam WC et al. Effects of single nucleotide polymorphisms in the RANTES promoter region in healthy and HIV-infected indigenous Chinese. Eur J Immunogenet. 2004; 31:179-83.

89. McDermott DH, Beecroft MJ, Kleeberger CA, Al-Sharif FM, Ollier WE, Zimmerman PA et al. Chemokine RANTES promoter polymorphism affects risk of both HIV infection and disease progression in the Multicenter AIDS Cohort Study. AIDS. 2000; 14:2671-8.

90. Wang C, Song W, Lobashevsky E, Wilson CM, Douglas SD, Mytilineos $\mathrm{J}$ et al. Cytokine and chemokine gene polymorphisms among ethnically diverse North Americans with HIV-1 infection. J Acquir Immune Defic Syndr. 2004; 35:446-54.

91. Vidal F, Peraire J, Domingo P, Broch M, Cairo M, Pedrol E et al. Chemokines and Long-Term Nonprogressive HIV01 Infection Study Group. Polymorphism of RANTES chemokine gene promoter is not associated with long-term nonprogressive HIV-1 infection of more than 16 years. J Acquir Immune Defic Syndr. 2006; 41:17-22.

92. Nakajima K, Tanaka Y, Nomiyama T, Ogihara T, Ikeda F, Kanno $\mathrm{R}$ et al. RANTES promoter genotype is associated with diabetic nephropathy in type 2 diabetic subjects. Diabetes Care. 2003; 26:892-8.

93. Liao CH, Yao TC, Chung HT, See LC, Kuo ML, Huang JL. Polymorphisms in the promoter region of RANTES and the regulatory region of monocyte chemoattractant protein-1 among Chinese children with systemic lupus erythematosus. J Rheumatol. 2004; 31:2062-7.

94. Ye DQ, Yang SG, Li XP, Hu YS, Yin J, Zhang GQ et al. Polymorphisms in the promoter region of RANTES in Han Chinese and their relationship with systemic lupus erythematosus. Arch Dermatol Res. 2005; 297:108-13.

95. Heydtmann M, Shields P, McCaughan G, Adams D. Cytokines and chemokines in the immune response to hepatitis $\mathrm{C}$ infection. Curr Opin Infect Dis. 2001; 14:279-87.
96. Promrat K, Liang TJ. Chemokine systems and hepatitis $\mathrm{C}$ virus infection: is truth in the genes of the beholders? Hepatology. 2003; $38: 1359-62$.

97. Fleury S, Li J, Simeoni E, Fiorini E, von Segesser LK, Kappenberger L et al. Gene transfer of RANTES and MCP-1 chemokine antagonists prolongs cardiac allograft survival. Gene Ther. 2006.

98. Botella C, Marin L, Moya-Quiles R, Miras M, Sanchez-Bueno F, Minguela A et al. Lack of association between the -403G/A promoter polymorphism in the human CCL5/RANTES chemokine gene in liver transplant outcome. Transpl Int. 2006; 19:98-104.

99. Wang CR, Guo HR, Liu MF. RANTES promoter polymorphism as a genetic risk factor for rheumatoid arthritis in the Chinese. Clin Exp Rheumatol. 2005; 23:379-84.

100. Makki RF, al Sharif F, Gonzalez-Gay MA, Garcia-Porrua C, Ollier WE, Hajeer AH. RANTES gene polymorphism in polymyalgia rheumatica, giant cell arteritis and rheumatoid arthritis. Clin Exp Rheumatol. 2000; 18:391-3.

101. Samson M, Libert F, Doranz BJ, Rucker J, Liesnard C, Farber $\mathrm{CM}$ et al. Resistance to HIV-1 infection in caucasian individuals bearing mutant alleles of the CCR-5 chemokine receptor gene. Nature. 1996; 382:722-5.

102. Wang FS, Hong WG, Cao Y, Liu MX, Jin L, Hu LP et al. Population survey of CCR5 delta32, CCR5 m303, CCR2b 64I, and SDF1 3'A allele frequencies in indigenous Chinese healthy individuals, and in HIV-1-infected and HIV-1-uninfected individuals in HIV-1 risk groups. J Acquir Immune Defic Syndr. 2003; 32:124-30.

103. Lucotte G, Mercier G. Distribution of the CCR5 gene 32-bp deletion in Europe.J Acquir Immune Defic Syndr Hum Retrovirol. 1998; 19:174-7.

104. Mummidi S, Bamshad M, Ahuja SS, Gonzalez E, Feuillet PM, Begum $\mathrm{K}$ et al. Evolution of human and non-human primate CC chemokine receptor 5 gene and mRNA. Potential roles for haplotype and mRNA diversity, differential haplotype-specific transcriptional activity, and altered transcription factor binding to polymorphic nucleotides in the pathogenesis of HIV-1 and simian immunodeficiency virus. J Biol Chem 2000; 275:18946-61.

105. Shieh B, Liau YE, Hsieh PS, Yan YP, Wang ST, Li C. Influence of nucleotide polymorphisms in the CCR2 gene and the CCR5 promoter on the expression of cell surface CCR5 and CXCR4. Int Immunol. 2000; 12:1311-8.

106. Martin MP, Dean M, Smith MW, Winkler C, Gerrard B, Michael NL et al. Genetic acceleration of AIDS progression by a promoter variant of CCR5. Science. 1998; 282:1907-11.

107. Ghilardi G, Biondi ML, Battaglioli L, Zambon A, Guagnellini E, Scorza R. Genetic risk factor characterizes abdominal aortic aneurysm from arterial occlusive disease in human beings: CCR5 Delta 32 deletion. J Vasc Surg. 2004; 40:995-1000.

108. Petrkova J, Cermakova Z, Lukl J, Petrek M. CC chemokine receptor 5 (CCR5) deletion polymorphism does not protect Czech males against early myocardial infarction. J Intern Med. 2005; 257:564-6.

109. Ortlepp JR, Schmitz F, Mevissen V, Weiss S, Huster J, Dronskowski $\mathrm{R}$ et al. The amount of calcium-deficient hexagonal hydroxyapatite in aortic valves is influenced by gender and associated with genetic polymorphisms in patients with severe calcific aortic stenosis. Eur Heart J. 2004; 25:514-22.

110. Kantor R, Bakhanashvili M, Achiron A. A mutated CCR5 gene may have favorable prognostic implications in MS. Neurology. 2003; 61:238-40

111. Sellebjerg F, Madsen HO, Jensen CV, Jensen J, Garred P. CCR5 delta32, matrix metalloproteinase-9 and disease activity in multiple sclerosis. J Neuroimmunol. 2000; 102:98-106.

112. Silversides JA, Heggarty SV, McDonnell GV, Hawkins SA, Graham CA. Influence of CCR5 delta32 polymorphism on multiple sclerosis susceptibility and disease course. Mult Scler. 2004; 10:149-52.

113. Kantarci OH, Morales Y, Ziemer PA, Hebrink DD, Mahad DJ, Atkinson EJ et al. CCR5Delta32 polymorphism effects on CCR5 expression, patterns of immunopathology and disease course in multiple sclerosis. J Neuroimmunol. 2005; 169:137-43. 
114. Favorova OO, Andreewski TV, Boiko AN, Sudomoina MA, Alekseenkov AD, Kulakova OG et al. The chemokine receptor CCR5 deletion mutation is associated with MS in HLA-DR4positive Russians. Neurology. 2002; 59:1652-5.

115. Zapico I, Coto E, Rodriguez A, Alvarez C, Torre JC, Alvarez V. CCR5 (chemokine receptor-5) DNA-polymorphism influences the severity of rheumatoid arthritis. Genes Immun. 2000; 1:288-9.

116. Pokorny V, McQueen F, Yeoman S, Merriman M, Merriman A, Harrison A et al. Evidence for negative association of the chemokine receptor CCR $5 \mathrm{~d} 32$ polymorphism with rheumatoid arthritis. Ann Rheum Dis. 2005; 64:487-90.

117. Petrek M, Cermakova Z, Hutyrova B, Micekova D, Drabek J, Rovensky $\mathrm{J}$ et al. CC chemokine receptor 5 and interleukin-1 receptor antagonist gene polymorphisms in patients with primary Sjogren's syndrome. Clin Exp Rheumatol. 2002; 20:701-3.

118. Spagnolo P, Renzoni EA, Wells AU, Copley SJ, Desai SR, Sato $\mathrm{H}$ et al. C-C chemokine receptor 5 gene variants in relation to lung disease in sarcoidosis. Am J Respir Crit Care Med. 2005; 172:721-8.

119. Hall IP, Wheatley A, Christie G, McDougall C, Hubbard R, Helms PJ. Association of CCR5 delta32 with reduced risk of asthma. Lancet 1999; 354:1264-5.

120. Mitchell TJ, Walley AJ, Pease JE, Venables PJ, Wiltshire S, Williams TJ et al. Delta 32 deletion of CCR5 gene and association with asthma or atopy. Lancet. 2000; 356:1491-2.

121. Sandford AJ, Zhu S, Bai TR, Fitzgerald JM, Pare PD. The role of the C-C chemokine receptor-5 Delta32 polymorphism in asthma and in the production of regulated on activation, normal $\mathrm{T}$ cells expressed and secreted. J Allergy Clin Immunol. 2001; 108:6973.

122. Lusso P. HIV and the chemokine system: 10 years later. EMBO J. 2006; 25:447-56

123. O'Brien SJ, Moore JP. The effect of genetic variation in chemokines and their receptors on HIV transmission and progression to AIDS. Immunol Rev. 2000; 177:99-111.

124. An P, Martin MP, Nelson GW, Carrington M, Smith MW, Gong $\mathrm{K}$ et al. Influence of CCR5 promoter haplotypes on AIDS progression in African-Americans. AIDS. 2000; 14:2117-22.

125. Ometto L, Bertorelle R, Mainardi M, Zanchetta M, Tognazzo $\mathrm{S}$, Rampon $\mathrm{O}$ et al. Polymorphisms in the CCR5 promoter region influence disease progression in perinatally human immunodeficiency virus type 1-infected children. J Infect Dis. 2001; 183:814-8.

126. Winkler CA, Hendel H, Carrington M, Smith MW, Nelson GW, O'brien SJ et al. Dominant effects of CCR2-CCR5 haplotypes in HIV-1 disease progression. J Acquir Immune Defic Syndr. 2004; 37:1534-8.

127. McDermott DH, Zimmerman PA, Guignard F, Kleeberger CA, Leitman SF, Murény PM. CCR5 promoter polymorphism and HIV-1 disease progression. Multicenter AIDS Cohort Study (MACS). Lancet Lancet. 1998; 352:866-70.

128. Clegg AO, Ashton LJ, Biti RA, Badhwar P, Williamson P, Kaldor JM et al. The Australian Long-Term Non-Progressor Study Group, CCR5 promoter polymorphisms, CCR5 59029A and CCR5 59353C, are under represented in HIV-1-infected long-term nonprogressors. AIDS 2000; 14:103.

129. Singh KK, Barroga CF, Hughes MD, Chen J, Raskino C, McKinney RE et al. Genetic influence of CCR5, CCR2, and SDF1 variants on human immunodeficiency virus 1 (HIV-1)-related disease progression and neurological impairment, in children with symptomatic HIV-1 infection. J Infect Dis. 2003; 188:146172 .
130. Li M, Song R, Masciotra S, Soriano V, Spira TJ, Lal RB et al. Association of CCR5 human haplogroup E with rapid HIV type 1 disease progression.AIDS Res Hum Retroviruses 2005; 21:1115 .

131. Kalev I, Oselin K, Parlist P, Zilmer M, Rajasalu T, Podar T et al. CC-chemokine receptor CCR5-del32 mutation as a modifying pathogenetic factor in type I diabetes. J Diabetes Complications. 2003; 17:387-91.

132. Mlynarski WM, Placha GP, Wolkow PP, Bochenski JP, Warram $\mathrm{JH}$, Krolewski AS. Risk of diabetic nephropathy in type 1 diabetes is associated with functional polymorphisms in RANTES receptor gene (CCR5): a sex-specific effect. Diabetes. 2005; 54:3331-5.

133. Nakajima K, Tanaka Y, Nomiyama T, Ogihara T, Piao L, Sakai $\mathrm{K}$ et al. Chemokine receptor genotype is associated with diabetic nephropathy in Japanese with type 2 diabetes. Diabetes. 2002; 51:238-42.

134. Woitas RP, Ahlenstiel G, Iwan A, Rockstroh JK, Brackmann $\mathrm{HH}$, Kupfer B et al. Frequency of the HIV-protective CC chemokine receptor $5 \Delta 32 / \Delta 32$ genotype is increased in hepatitis $C$. Gastroenterology 2002; 122:1721-28.

135. Zhang M, Goedert JJ, O'brien TR. High frequency of CCR5delta32 homozygosity in HCV-infected, HIV-1-uninfected hemophiliacs results from resistance to HIV-1. Gastroenterology 2003; 124:867-68

136. Chang HY, Ahn SH, Kim do Y, Shin JS, Kim YS, Hong SP et al. Association between CCR5 promoter polymorphisms and hepatitis B virus infection Korean J Hepatol. 2005; 11:116-24.

137. Fildes JE, Walker AH, Howlett R, Bittar MN, Hutchinson IV, Leonard CT et al. Donor CCR5 Delta32 polymorphism and outcome following cardiac transplantation. Transplant Proc. 2005; 37:2247-9.

138. Hoffmann S, Park J, Jacobson LM, Muehrer RJ, Lorentzen D, Kleiner $\mathrm{D}$ et al. Donor genomics influence graft events: the effect of donor polymorphisms on acute rejection and chronic allograft nephropathy. Kidney Int. 2004; 66:1686-93.

139. Moench C, Uhrig A, Lohse AW, Otto G. CC chemokine receptor $5 \Delta 32$ polymorphism-a risk factor for ischemic-type biliary lesions following orthotopic liver transplantation. Liver Transpl. 2004; 10:434-9.

140. Aguilar F, Nunez-Roldan A, Torres B, Wichmann I, SanchezRoman J, Gonzalez-Escribano MF. Chemokine receptor CCR2/ CCR5 polymorphism in Spanish patients with systemic lupus erythematosus. J Rheumatol. 2003; 30:1770-4.

141. Degerli N, Yilmaz E, Bardakci F. The delta32 allele distribution of the CCR5 gene and its relationship with certain cancers in a Turkish population. Clin Biochem. 2005; 38:248-52.

142. Dean M, Jacobson LP, McFarlane G, Margolick JB, Jenkins FJ, Howard OM et al. Reduced risk of AIDS lymphoma in individuals heterozygous for the CCR5-delta32 mutation. Cancer Res. 1999; 59:3561-4.

143. Ortlepp JR, Vesper K, Mevissen V, Schmitz F, Janssens U, Franke A et al. Chemokine receptor (CCR2) genotype is associated with myocardial infarction and heart failure in patients under 65 years of age. J Mol Med. 2003; 81:363-7.

144. Alonso-Villaverde C, Coll B, Parra S, Montero M, Calvo N, Tous $\mathrm{M}$ et al. Atherosclerosis in patients infected with HIV is influenced by a mutant monocyte chemoattractant protein-1 allele. Circulation. 2004; 110:2204-9.

145. Yao TC, Wu KC, Chung HT, Shaw CK, Kuo ML, Wu CJ, Huang JL. MCP-1 gene regulatory region polymorphism in Chinese children with mild, moderate and near-fatal asthma. Allergy. 2004; 59:436-41. 